Available online on 15.02 .2020 at http://ajprd.com
(C) 2013-20, publisher and licensee AJPRD, This is an Open Access article which permits unrestricted non-
commercial use, provided the original work is properly cited

Open $\overbrace{\text { Access }}$

Research Article

\title{
Phytochemicals Analysis and Cytotoxicity Activity of Ethanol Extract of Litseacubeba Lour.Heartwood
}

\section{Fujiko M. ${ }^{*}$, Dalimunthe A. ${ }^{*}$, Masfria $\mathbf{M}^{2}$,}

1Department of Pharmacology, Faculty of Pharmacy, Universitas Sumatera Utara, Medan, 20155, Indonesia.

2Department of Pharmaceutical Chemistry, Faculty of Pharmacy, Universitas Sumatera Utara, Medan, 20155, Indonesia

\begin{abstract}
A B S T R A C T
Objective: The purpose of this study was to determine the chemical compounds whichcontained in the ethanol extract and cytotoxic activity ethanol extract of Litseacubeba heartwood induced in T47D cells.

Methods: The ethanol extract was extracted by maceration using ethanol $96 \%$ solvent. Cytotoxic activity was determined with MTT method and the $\mathrm{IC}_{50}$ analyzed using SPSS 23.

Results: Phytochemicals screening were showed that the ethanol extract of Litseacubeba heartwood contained steroids/triterpenoids, glycosides, alkaloids, flavonoids, saponins and tannins. The $\mathrm{IC}_{50}$ of ethanol extract of Litseacubeba heartwood were $349,57 \pm 0,35 \mu \mathrm{g} / \mathrm{ml}$ in $\mathrm{T} 47 \mathrm{D}$ cells.

Conclusions: Ethanol extract of Litseacubeba heartwood has activity as an anticancer to T47D cells breast cancer agents.
\end{abstract}

Keywords: heartwood, Litseacubeba Lour, T47D cell, cytotoxicity, phytochemicals.

A R T I C L E I N F 0: Received 05 Nov 2019. $\quad$ Review Completed 11 Jan. 2020; $\quad$ Accepted 27 Jan. $2020 ;$

Available online 15 Feb. 2020

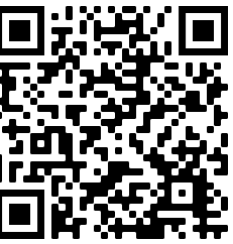

Cite this article as:

Fujiko M, Dalimunthe A, Masfria M, Phytochemicals Analysis and Cytotoxicity Activity of Ethanol Extract of Litseacubeba Lour.Heartwood, Asian Journal of Pharmaceutical Research and Development. 2020; 8(1):14-17.

DOI: http://dx.doi.org/10.22270/ajprd.v8i1.643

*Address for Correspondence:

Fujiko M, Department of Pharmacology, Faculty of Pharmacy, Universitas Sumatera Utara, Medan, 20155, Indonesia

\section{INTRODUCTION}

$\mathrm{A}$ ttarasa is a plant from the Lauraceae family that contains bioactive alkaloids, essential oils, flavonoids and steroids, which in this plant also contains total phenolic and flavonoids which are known to have antioxidant functions ${ }^{1}$. Traditionally, essential oils in attarasa plants are used as an antidepressant, antiinflammatory, antioxidant, pesticide, antimicrobial, anticancer and neuro pharmacological agent ${ }^{2}$. Piyapat et al. stated that methanol extract from attarasa fruits has an activity that causes apoptosis by activating the caspase $3 / 7$ against Hela cells. Isoquinolone alkaloids can be used as inhibitors of the cholinesterase enzyme, wherein the inhibition of the enzyme coninesterase can treat alzaimer disease, Parkinson's disease, and inhibitors of premature aging $^{3}$.

Cancer is a disease that is very complex and is ranked first as the leading cause of death worldwide ${ }^{4}$. The most common type of cancer suffered by women is breast cancer (30\% of all cancer cases in women), and $14 \%$ of these cases end in death $^{5}$. Handling cancer with chemotherapy agents is still an option in cancer treatment. However, the presence of a multidrug resistance (MDR) mechanism results in reduced efficacy of chemotherapy drugs ${ }^{6}$. Some research began to be directed at testing the potential of natural ingredients as chemoprevention agents that have the potential as chemotherapy companion agents ${ }^{7}$. The aim is to increase the sensitivity of cancer cells and reduce the side effects caused by chemotherapy agents ${ }^{8}$. Chemoprevention agents referred to here generally have the activity of inhibiting tumor growth through the mechanism of cell cycle arrest, apoptosis tracking or inhibiting the expression of proteins that play a role in Multi Drug Resistance 9

Chemopreventive agents can reduce the risk of cancer by inhibiting the initiation of preneoplastic lesions by carcinogens, or reversing cancer progression. One approach 
to finding chemopreventive compounds is through exploration of natural materials, especially plants ${ }^{10}$. The chemical composition of the heartwood in this study is intended to determine the characteristics and content of chemical compounds and to know the anticancer activity of Litseacubeba heartwood extract.

\section{EXPERIMENTAL}

\section{Plant and chemicals materials}

Fresh heartwood of Litseacubeba (Lour.) were collected from Parsoburan Village, Toba Samosir, North Sumatra, Indonesia. Litseacubeba Lour. was identified in Herbarium Medanense (MEDA) Universityof Sumatera Utara. The chemicals materials used in this study were ethanol $96 \%$, Hepes (Sigma), dimethyl sulfoxide (DMSO) (Sigma), DMEM media, RPMI-1640 media, FBS (Gibco), penicillinstreptomycin (Gibco), Fungizon (Amphotericin B) 0.5\%, trypsin-EDTA $0.25 \%$ (Gibco), Fetal Bovine Serum (Gibco), PBS, and [3-(4,5-dimethylthiazol-2-il)-2,5 difeniltetrazolium bromide] ( Sigma).

\section{Preparation of extractethanol Litseacubeba Lour. Heartwood}

The air-dried and powdered heartwood of Litseacubeba (Lour,) $(1 \mathrm{~kg})$ were repeatedly macerated with ethanol $96 \%$ $(3 \times 3 \mathrm{~d}, 7.5 \mathrm{~L})$, the filtrate was evaporated with a rotary evaporator with a temperature of $\pm 40^{\circ} \mathrm{C}$ to give a viscous extract ${ }^{11}$.

\section{Phytochemical analysis of ethanol extract Litseacubeba Lour.heartwood}

Phytochemical analysis was performed on ethanol extract of heartwood Litseacubeba Lour. Included examination of secondary metabolites of alkaloids, flavonoids, glycosides, tannins, saponins and triterpenoids/steroids were carried out according to standard procedures ${ }^{12}$.

\section{Dosage of extract}

The treatment of extract used several concentration series of $500 \mu \mathrm{g} / \mathrm{mL} ; 250 \mu \mathrm{g} / \mathrm{mL} ; 125 \mu \mathrm{g} / \mathrm{mL} ; 62.5 \mu \mathrm{g} / \mathrm{mL} ; 31.25 \mu \mathrm{g}$ $/ \mathrm{mL}$ and $15.625 \mu \mathrm{g} / \mathrm{mL}$.

\section{Cytotoxicity AssayAnd Selectivity Index}

T47D cells were grown on RPMI media supplemented with 10\% (Gibco) Fetal bovine, Penicillin 1\% Streptomycin 1\% (Gibco) and Fungizone $0.5 \%$ (Gibco) were incubated at $37^{\circ} \mathrm{C}, \mathrm{CO} 25 \%$. The inoculums seeded on a 96 well plate (Iwaki), each well $1 \times 104$ cells $/ 0.1 \mathrm{~mL}$. Cell culture were incubated at $37^{\circ} \mathrm{C}, 5 \% \mathrm{CO} 2$ for 24 hours. After 24 hours the media was discarded and the cell plus ethanol extract and doxorubicin were incubated for 24 hours then the medium was removed and $0.5 \mathrm{mg} / \mathrm{mL}$ of MTT was added and incubated for 4 hours at $37^{\circ} \mathrm{C}, 5 \% \mathrm{CO} 2$. after crystal formazan was formed and 10\% SDS was added to dissolve the formazan crystals, then incubated for 24 hours at room temperature and shielded from light. The absorbance was measured with microplate reader at $\lambda 595 \mathrm{~nm}$. The resulting absorbance was converted to a percentage of cell viability, then the selectivity index (IS) ethanol extract was determined against T47D cells ${ }^{13}$.
The equation to determine the viability of cells

$$
\% \text { Viability }=\frac{\text { Absorbance of treatment- absorbance of medium }}{\text { absorbance of control cells }- \text { absorbance of medium }}
$$

\section{Statistical Analysis}

The results were presented as means \pm SD. The statistical analysis was carried out byusing SPSS edition 23 .

\section{RESULT AND DISCUSSION}

The results of phytochemicals constituent analysis from ethanol extract of heartwood Litseacubeba Lour.were determined to obtain the information of the group of phytochemical which contain in Litseacubeba Lour. The resultscan be seen on Table 1. Alkaloids from ethanol extract $^{11}$ and Phenolic; flavonoid from ethyl acetate extract ${ }^{1}$ were identified active as antioxidant activity, alkaloids fraction active as inhibited the development cell cancers $^{14}$.

Table 1: Phytochemicals content heartwood of Litseacubeba Lour.

\begin{tabular}{|l|l|l|l|}
\hline No & Metabolite secondary & Simplicia & Extract \\
\hline 1 & Alkaloids & + & + \\
\hline 2 & Flavonoids & + & + \\
\hline 3 & Saponin & + & + \\
\hline 4 & Tanins & + & + \\
\hline 5 & Glikosid & + & + \\
\hline 6 & Steroid/Triterpenoid & + & + \\
\hline
\end{tabular}

Description: (+) shows that the simplicia and ethanol extract contains secondary metabolite, (-) shows that the simplicia and ethanol extract not contain secondary metabolite. Phytochemical compounds in simplicia and ethanol extract isn't different.

Cytotoxic effect of ethanol extract Litseacubeba Lour. was carried out by MTT method [3- (4,5-dimethyl thiazol-2-il) 2,5-diphenyltetrazolium bromide] was used to determine cell viability in each observation as indicated by $\mathrm{IC}_{50}$ values which could inhibit cell growth after being treated and incubated for 24 hours. Inhibition of cell growth is indicated by $\mathrm{IC}_{50}$ values ${ }^{13}$. The result of $\mathrm{Ic}_{50}$ can be seen in the Table 2 .

Table 2: $\mathrm{IC}_{50}(\mathrm{ug} / \mathrm{mL})$ ethanol extract of LitseacubebaLour.againstT47D cell

\begin{tabular}{|l|l|}
\hline Sample & $\mathbf{I C}_{50}(\mathbf{u g} / \mathbf{m L})$ \\
\hline Heartwood of Litseacubeba Lour & $349.57 \pm 0,35$ \\
\hline
\end{tabular}

Description: $\mathrm{IC}_{50}$ was measured using MTT method, ethanol extract of Litsea cubeba Lour.

$\mathrm{IC}_{50}$ values obtained from ethanol extract of heartwood Litseacubeba Lour.againstT47D cells were $349.57 \pm 0,35 \mu \mathrm{g} /$ mL.Dalimunthe ${ }^{14}$ states that an extract which is declared active when giving an $\mathrm{IC}_{50}$ value of $10-100 \mu \mathrm{g} / \mathrm{ml}$, with the results obtained from the alkaloid fraction of attarasa heartwood and fruit at $\mathrm{pH} 7$ and 9 were $46.60 \pm 0.19 ; 123.01$ $\pm 14.63 \mathrm{dan} 35.89 \pm 1.04 ; 98.31 \pm 2.51 \mu \mathrm{g} / \mathrm{mL}$. The smaller the $\mathrm{IC}_{50}$ value means the higher the value of its cytotoxic activity. Cytotoxicity can be grouped into three namely: (1)

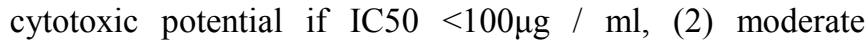


cytotoxic if $100 \mu \mathrm{g} / \mathrm{ml}<\mathrm{IC} 50<1000 \mu \mathrm{g} / \mathrm{ml}$ and non-toxic if IC50> $1000 \mu \mathrm{g} / \mathrm{ml}$. Groups of compounds with potential cytotoxicity can be used as anticancer agents while moderate cytotoxicity can be used for chemoprevention that can prevent and inhibit the growth of cancer cells15.NCI (National Cancer Institute) has established anticancer activity criteria based on Inhibition Concentration $50\left(\mathrm{IC}_{50}\right)$, which is the concentration of substances needed to inhibit cell growth by $50 \%$. A substance is called cytotoxic (anticancer) if its activity on a test has an $\mathrm{IC}_{50}$ value $<4 \mu \mathrm{g} / \mathrm{mL}^{16}$.

Ethanol extract of Litsea cubeba Lour. cytotoxic activity was also showed by changes in T47D cells morphology and viability data after treatment. T47D cells morphology and viability data can be seen in figure 1 and figure 2 .

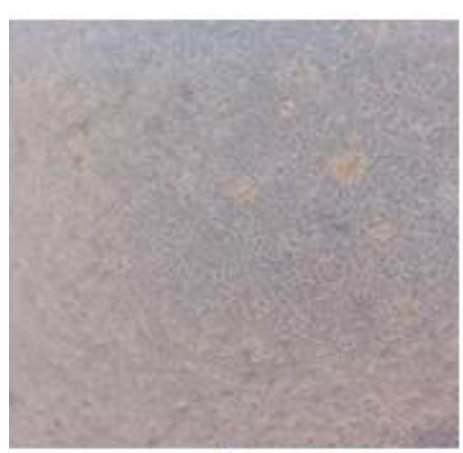

A

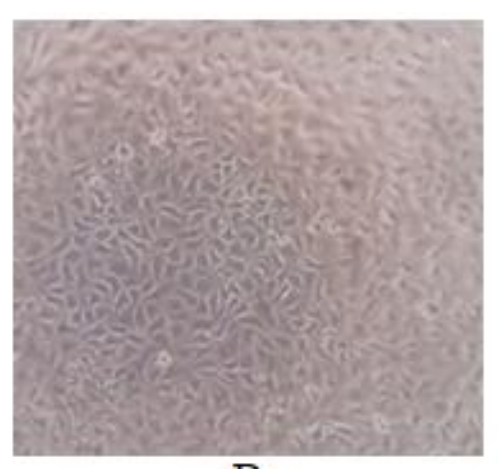

B

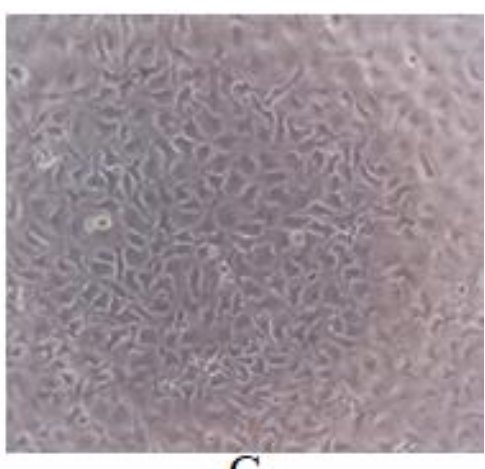

$\mathrm{C}$

Figure 1: The cytotoxic effect of the sample on T47D cell. The observation was performed under inverted microscope with 100x magnification. A: Ethanol Extract $500 \mathrm{ug} / \mathrm{mL}$, B: Ethanol Extract 31.25ug/mL, C: Control Cell

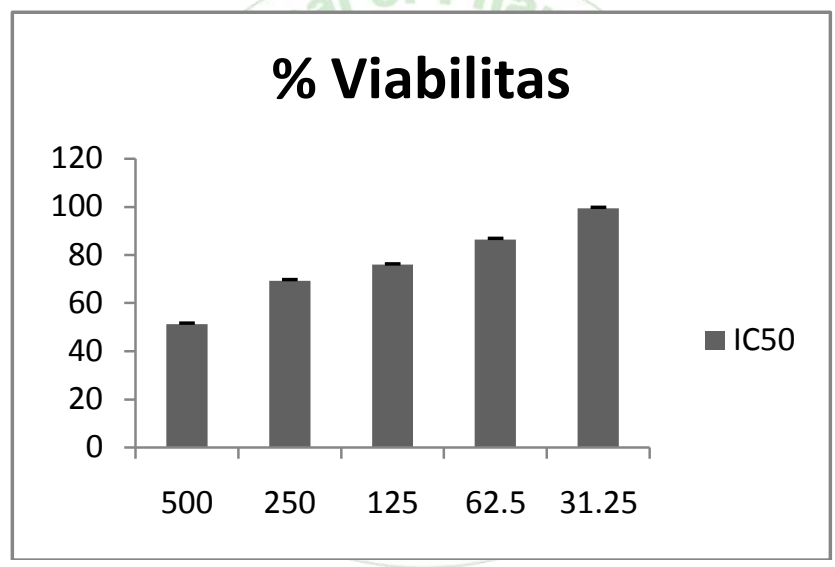

Figure 2: Percentage of viability Ethanol Extract of Litseacubeba $(500 \mu \mathrm{g} / \mathrm{ml}, 250 \mu \mathrm{g} / \mathrm{ml}, 125 \mu \mathrm{g} / \mathrm{ml}, 62.5 \mu \mathrm{g} / \mathrm{ml}$ and $31.25 \mu \mathrm{g} / \mathrm{ml}$ ) on T47D cell.

From figure 1, can viewed ethanol extract leaded death in T47 D Cell morphology was changed and having damaged. If concentration of ethanol extract was increased, then it will cause percentage of viability will decreased. Figure 2 showed, an increased in ethanol extract concentration caused decreased percentage of viability at $51,25 \%, 69,21 \%, 75$, $96 \%, 86,41 \%$ and $99,32 \%$.

\section{CONCLUSION}

Based on the results we obtained ethanol extract of heartwood Litseacubeba Lour.hada potentially used as to cochemotherapy agent for breast cancer therapy.

\section{ACKNOWLEDGMENTS}

We gratefully thank to Ministry of Research, Technology and Higher Education through "Hibah Penelitian Dasar Unggulan Perguruan Tinggi” research grant 2019 for financial support in the study.

\section{REFERENCES}

1. Dalimunthe, A., Achmad, S., and Satria, D. (2016). Phenolic, flavonoid content and antioxidant activities of ethylacetate extract of Litsea cubeba (Lour.) Pers. Heartwoods. Der Pharma Chemica.2016; 8: 466468.

2. Trisonthi P, Sato A, Nishiwaki H, Tamura H. A new diterpene from Litseacubeba fruits: structure elucidation and capability to induce apoptosis in HeLa cells. Molecules. 2014 May 23; 19(5):6838-50.

3. Atta-ur-Rahman. (2009). Bisbenzylisoquinoline alkaloids from Cocculus pendulus. Natural Product Research.2009; 23(14):1265-1273.

4. Torre LA, et al. (2015.) Global cancer statistics, CA Cancer J Clin. 2015; 1:65(2):87- 108 .

5. Siegel RL, Miller KD, and Jemal A. Cancer statistics, CA Cancer J Clin.2017; 1:67(1):7-30.

6. Conze, D. et al., Autocrine Production of Interleukin 6 Causes Multi Drug Resistance In Breast Cancer Cells. Cancer Research. 2001; 61. 8851-8858.

7. Shapiro, G.I., and Harper, J.W.,Anticancer Drug Targets: Cell Cycle and Checkpoint Control, J. Clin. Invest., 1999; 104, 1645-1653.

8. Fisher, D.E., Apoptosis in Cancer Therapy: Crossing The Threshold. Cell. 1994; 78. 539-542. 
9. Kitagawa, S.Inhibitory Effect of Polyphenols on P-GlycoproteinMediated Transport, Biol. Pharm Bull. 2006; 29, 1-6.

10. Desai AG, et al. Medicinal plants and cancer chemoprevention. Curr Drug Metab.2008 ; 9(7):581-591.

11. Dalimunthe, A., Poppy, A., Jansen, S., Siti, F., and Denny, S., (2018). Antioxidant Activity of Alkaloid Compounds from Litsea cubeba Lour. Oriental Journal of Chemistry, 2018; 34: 1149-1152.

12. D. Satria, J. Silalahi, G. Haro, S. Ilyas, P. A. Z. Hasibuan. Chemical Analysis and Cytotoxic Activity of N-Hexane Fraction of ZanthoxylumacanthopodiumDC. Fruits. Rasayan J Chem. 2019; 12(2):803-808.

13. Hutagaol, Sherly.,Rosidah., Masfria., and Denny, S., Combination effect of ethylacetate extract leaves of Moringaoleifera $\mathrm{L}$. and Doxorubicin against MCF-7 cell lines. Journal of Innovations in Phramaceutical and Biological Sciences, 2018; 5(3) : 42-46.

14. Dalimunthe, A., Poppy, A., Jansen, S., and Denny, S., (2018). Aktivitas Sitotoksik Fraksi Alkaloid Kulit Batang dan Buah Attarasa (Litsea cubeba Lour.) terhadap Sel Kanker Payudara T47D. TM Conference Series 2018; $01: 052-055$.

15. Tussannti, Iin., Andrew Johan and Kisdjamiatun, 2014, Sitotoksisitas in vitro ekstraketanolikbuahparijoto (Medinillaspeciosa, reinw.ex bl.) terhadapselkankerpayudara T47D, Jurnal Gizi Indonesia, 2014; 2(2):1858-4942.

16. Suffness, M, Pezzuto, JM, Assays Related to Cancer Drug Discovery. In Methods in Plant Biochemistry: Assays for Bioactivity; Hostettmann, K, Ed.; Academic Press: London, UK, 1990; 6, 71-133. 